\title{
The Evaluation of the SWAT Model Performance to Predict the Runoff Values in the Iraqi Western Desert
}

\author{
Sadeq Oleiwi Sulaiman ${ }^{1}$, Nabeel Shaker Mahmood ${ }^{1}$, Ammar Hatem Kamel ${ }^{1}$, Nadhir Al-Ansari ${ }^{2, *}$ \\ ${ }^{1}$ College of Engineering, University of Anbar, Ramadi, 31001, Iraq \\ ${ }^{2}$ Civil, Environmental and Natural Resources Engineering, Lulea University of Technology, 97187 Lulea, Sweden
}

Received June 17, 2021; Revised August 23, 2021; Accepted September 21, 2021

\begin{abstract}
Cite This Paper in the following Citation Styles
(a): [1] Sadeq Oleiwi Sulaiman, Nabeel Shaker Mahmood, Ammar Hatem Kamel, Nadhir Al-Ansari, "The Evaluation of the SWAT Model Performance to Predict the Runoff Values in the Iraqi Western Desert," Environment and Ecology Research, Vol. 9, No. 6, pp. 330 - 339, 2020. DOI: 10.13189/eer.2021.090602.
\end{abstract}

(b): Sadeq Oleiwi Sulaiman, Nabeel Shaker Mahmood, Ammar Hatem Kamel, Nadhir Al-Ansari (2021). The Evaluation of the SWAT Model Performance to Predict the Runoff Values in the Iraqi Western Desert. Environment and Ecology Research, 9(6), 330 - 339. DOI: 10.13189/eer.2021.090602.

Copyright $\odot 2021$ by authors, all rights reserved. Authors agree that this article remains permanently open access under the terms of the Creative Commons Attribution License 4.0 International License

\begin{abstract}
In the present research, the Soil and Water Assessment Tool (SWAT) model was used for the prediction of surface runoff amounts of the catchment of Al-Masad, in the Western Desert of Iraq. The prediction period was from September 2020 to January 2030. The calibration and verification of this model were performed according to the daily surface runoff data that were measured between 2010 and 2014. Statistical parameters were employed to determine the performance of the model. These parameters were RSR (ratio of the root mean square error to the standard deviation of measured data), NSE (Nash-Sutcliffe efficiency), and PBias (percent Bias), which were calculated as $0.58 \%, 0.71 \%$, and $13 \%$ for calibration and $0.55 \%, 0.74 \%$ and $11 \%$ for verification, respectively. The results from the model verification and calibration prove that this model was sufficient in simulating the catchment surface runoff. Furthermore, the SWAT model was applied for the prediction of daily, monthly, and yearly surface runoff value of the catchment from 2021 to 2030 . The results obtained from the model showed that the annual surface runoff volume of the catchment, throughout the period of the simulation, was between 0.65 and 8.3 million $\mathrm{m}^{3}$ with an average value of 2.622 million $\mathrm{m}^{3}$.
\end{abstract}

Keywords Water Harvesting, Surface Runoff, SWAT Model, Iraqi Western Desert

\section{Introduction}

One of the main challenges that many societies are currently facing or may need to face during the next few years is the great scarcity in the amount of the available water resources as a result of the changing conditions of land use and climate change. There will be an urgent need to use integrated management and an appropriate allocation of water resources between different uses as well as optimum utilization of the available water resources [1][3]. The water resources in Iraq, particularly in the area of the Western desert, are facing several issues due to some of the predominant natural conditions such as draught, high evaporation rates as a result of the increase in the rates of temperature, and the breadth of the desertification phenomenon. Those conditions need exploring and studying the conventional resources of water which are available in that region such as groundwater and seasonal rainstorms flood [4]-[6]. Specifically, the seasonal runoff is a main source of water in the Western Desert of Iraq. The frequencies of rainstorms and prospects of runoff have to be studied according to the data and information that can be obtained from the field measures throughout the last few decades and according to the hydrological forecasts. For the purpose of the design of any project of water harvesting, the annual water amount should be assessed, and the surface runoff amounts of the drainage basin, which resulted from a specific rainstorm, should be calculated. Several models and solutions have been developed to estimate the surface runoff in various basins. Some of those 
models, such as SWAT model, have been developed based on the continuous simulation mathematical models. The SWAT model is a semi-distributed hydrological model. It was developed by the Department of Agriculture in the United States (USDA). The SWAT model has been essentially utilized for the estimation of watershed management practices impact on the surface runoff and the sediment transport in a major hydrological system [7]-[9]. The model was then advanced through the use of the equations of the Soil Conservation Service (SCS) and the Modified Universal Soil Loss Equation (MUSLE) [10].

The SWAT model efficiently simulates catchments with varied land use, land cover, soil properties, and ground terrain to estimate the amount of water that can be obtained from the basin following rainstorms [11], [12]. The application of the model required several variables such as daily rainfall, relative humidity, temperature, soil composition and type, vegetation state, and ground surface slope. Some of those variables vary from one area to the other in the basin. As such, the utilization of the remote sensing and geographic information systems (GIS) may be necessary to determine these variables. The SWAT model has been implemented in a number of countries on different types of catchments throughout the past years. This model has proven to be an inexpensive and reliable means of studying catchments management [13]-[18]. The SWAT model has been shown to be valid in the estimation of surface runoff for the majority of those catchment types.

The aim of the present study is to explore the morphological and spatial properties within Wadi Al-Masad basin water drainage network through the use of the SWAT model. The hydrological data that is available such as temperature, rainfalls, properties of the soil, relative humidity, land use, and land cover have been deployed by this model for the determination of the properties of the whole catchment that was studied. This model has been operated under GIS in the (Arc-SWAT) model.

\section{Materials and Methods}

The application of different hydrological models provides a scientific basis for the useful accomplishment of water resource management in different regions of the world. One of these models is SWAT model. This model classically deals with physical-based watershed measurements with considerable advantages in conjunction between surface water and groundwater. The model is requiring information to operate such as weather data, soil properties, topography, land use and land cover and vegetation and other basic data.

\subsection{Description of the Study Area}

Wadi Al-Masad basin is a sub-basin within Wadi Horan which is the largest catchment in the Western Desert of Iraq. Wadi Horan can be classified into several sub-catchments and its water flows from the west toward the east then the outlet of the Wadi discharged the water to the Euphrates near Al-Baghdadi city within Al-Anbar province. The area under investigation is located near Al-Rutba city west of Al-Anbar province between $32^{\circ} 39^{\prime}$ $18^{\prime \prime}$ and $32^{\circ} 51^{\prime} 36^{\prime \prime}$ latitudes North and $40^{\circ} 05^{\prime} 24^{\prime \prime}$ and $40^{\circ}$ 21' 36" longitudes East with a catchment area that was estimated to be $404 \mathrm{~km}^{2}$, as shown in Figure 1 [19]-[21]. Data that were utilized in the present work were obtained from the meteorological station of Al-Rutba which is the nearest station to the area of the study. This area climate is generally dry, where there is quite high temperature, in particular, throughout June, July, and August, with a maximal of temperature that reaches $41.70^{\circ} \mathrm{C}$ in July. The mean value of the minimum temperature is $24.8^{\circ} \mathrm{C}$. The minimum temperature is drastically decreased throughout December, January, and February to approximately $2.7^{\circ} \mathrm{C}$. The rainfall amount which has been received by this area is fluctuating throughout the years. The total mean annual rainfall is about $120 \mathrm{~mm}$. The maximum rainfall within the area is from September to May whereas rainfalls are unexpected between June and August. High evaporation rates were recorded in this area with a maximal $324.5 \mathrm{~mm}$ throughout July and a minimal $35.52 \mathrm{~mm}$ throughout January. Laboratory experiments that have been carried out on 5 samples of soil that were obtained from this area have shown that this soil is mainly sandy silt and loamy sand that has a high lime percentage of up to $151.7 \mathrm{~g} / \mathrm{kg}$. The variations in the components of the soil have a considerable influence upon the runoff of the surface following the rainstorms. Previously prepared maps and field visits to this area showed that the density of the vegetation has been quite low. The vegetation density has extremely influenced the hydrological conditions. The lower vegetation density has resulted in an increase in the surface run-off speed after rainstorms. 


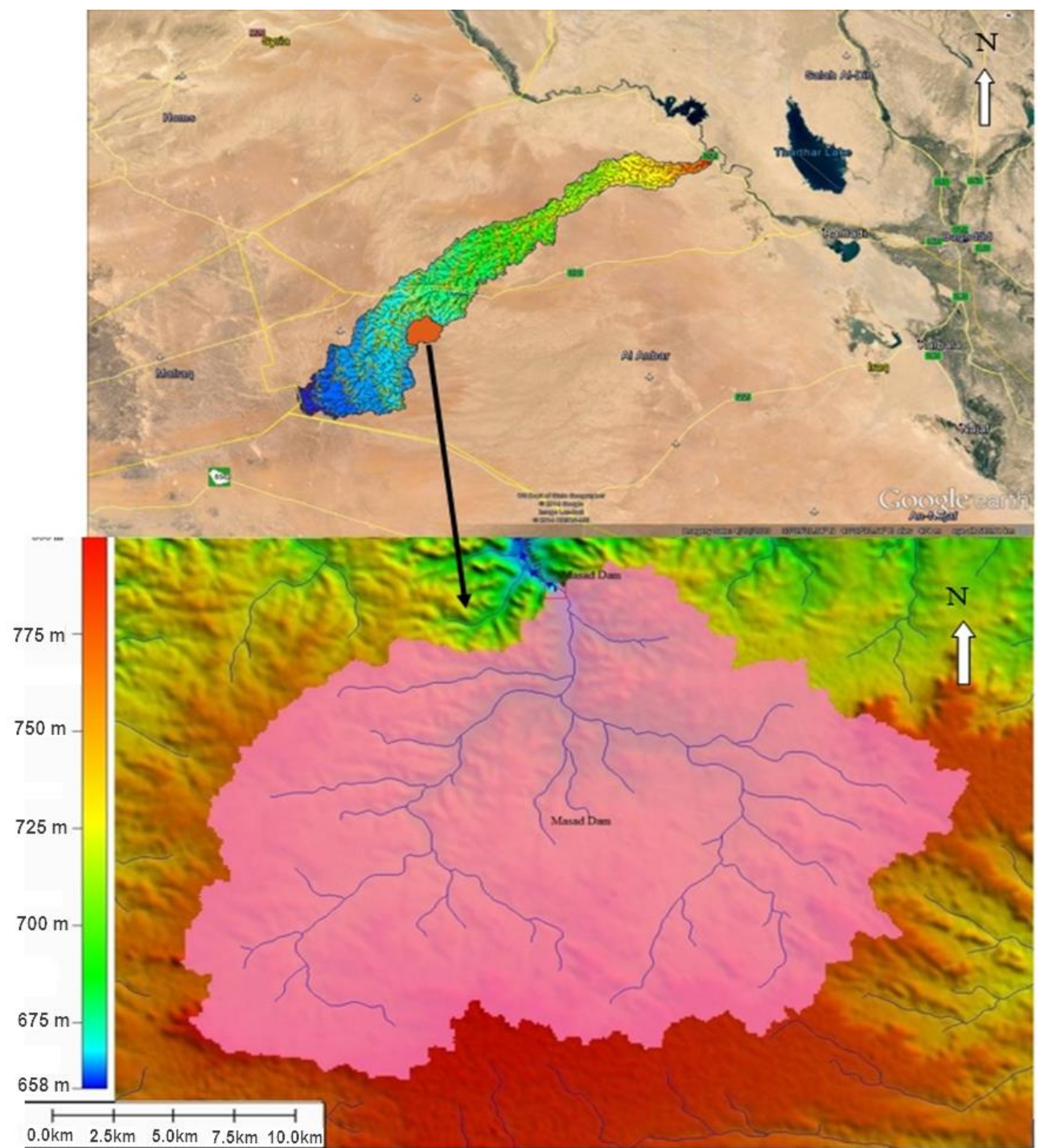

Figure 1. Location of the study area

\subsection{SWAT Model Description}

The SWAT model is one of the semi-empirical hydrological models which can be regulated based on the certain conditions of the drainage basin. This model has been utilized for the prediction of the surface runoff amounts, water quality, and sediment transport at the outlet of the drainage basin. This model may be implemented on 1-day time step [22]. The SWAT model is dependent upon a group of the theories and equations for the estimation of the surface runoff amount and sediments transport. The surface runoff is computed in SWAT by using water balance equation with employing the Soil Conservation Service method (SCS) for computing runoff depth. The estimation of surface runoff amount produced by daily rainfall was stated by the approach of the SCS, which has been referred to as the Curve Number $(\mathrm{CN})$ approach, was used as presented in equations 1 and 2 .

$$
\begin{gathered}
Q_{\text {surf }}=\frac{\left(P_{\text {day }}-0.2 S\right)^{2}}{\left(P_{\text {day }}+0.8 S\right)} \\
S=25.4\left(\frac{1000}{C N}-10\right)
\end{gathered}
$$

Where Q-surf represents the surface runoff depth from a rainstorm in $\mathrm{mm}$; $\mathrm{S}$ represents the coefficient of interception in $\mathrm{mm}$; P-day represents the daily rainfall depth from a rainstorm in $\mathrm{mm}$; and $\mathrm{CN}$ represents the curve number.

$\mathrm{CN}$ values calculated for each of the catchment maps cells is called hydrological response units (HRUs). Additionally, the SWAT model divides basin into several subbasins based on the elevation ranges in the study area and computes $\mathrm{CN}$ for each subbasin with the use of the chart that depends upon the catchment soil type, soil humidity, and land use for a number of days prior to rainstorm. Digital maps have been employed in the 
SWAT model for the purpose of classification of soil characteristics, land cover, and land use. There are three important steps to represent the SWAT model methodology: basin creation, identifying hydrological response units (HRUs), and determining the weather generation data, as shown in Figure 2 [23].

In addition to that, MUSLE (Modified Universal Soil Loss Equations) has been utilized by this model for the purpose of the estimation of the sediments amount that are transported over the catchment as a result of rains and surface runoff based on the process that has been suggested in 1995 by Williams, as stated in equation 3 [24-26].

$$
\text { Sed }=11.8\left(Q_{\text {surf }} \cdot q_{\text {peak }} \cdot \text { area } a_{\text {hru }}\right)^{0.5} K_{U S L E} \cdot C_{U S L E} \cdot L S_{U S L E} \cdot C_{F R G}
$$

Where: Sed represents the sediments that have been produced (in tons); $\mathrm{q}_{\text {peak }}$ represents the maximal runoff of the surface in $\mathrm{m}^{3} / \mathrm{sec} ; \mathrm{Q}_{\text {surf }}$ represents the runoff of the surface in $\mathrm{mm} / \mathrm{h}$; area $_{\mathrm{hru}}$ represents hydrological catchment area in hectares; $\mathrm{K}_{\mathrm{USLE}}$ represents the factor of soil erodibility; $\mathrm{P}_{\text {USLE }}$ represents the factor of erosion control practice; $\mathrm{C}_{\mathrm{USLE}}$ represents the factor of the cropping management; $\mathrm{C}_{\mathrm{FRG}}$ represents the factor of soil roughness; and $\mathrm{LS}_{\mathrm{USLE}}$ represents the topographic factor.

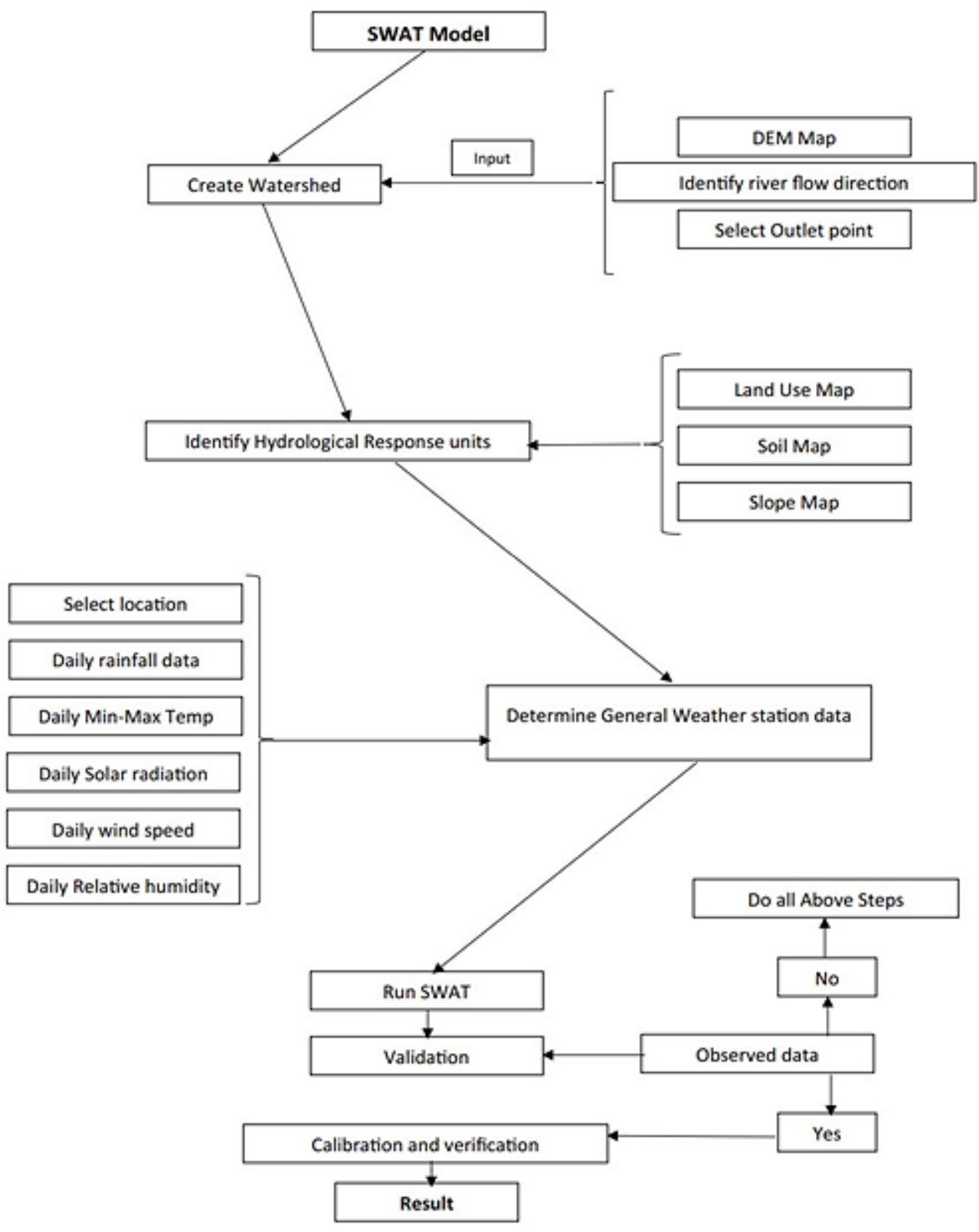

Figure 2. The SWAT model methodology (from [23]) 


\subsection{Methodology}

The ArcSWAT model was used to evaluate Al-Masad basin morphological and spatial properties according to the available local field measurements and climate data. This section describes the method of obtaining and processing of the input data of the model. The field data, GIS tools, and ArcSWAT model tools were employed to obtain the needed data. The main input data are Digital Elevation Model (DEM), land use map, soil map, and weather data.

Digital Elevation Model (DEM): Digital Elevation Model (DEM) is an important element of the ArcSWAT input data for the purposes of watershed delineation of reaches streams and watersheds borders. The DEM with $90 \mathrm{~m}$ resolution from the Shuttle Radar Topography Mission Digital Elevations Model (SRTM DEM) was used in this study.

Land Use Map: Land use classes are used in ArcSWAT software for the purposes of computing curve number for each sub-basin within the watershed. Land use map that was used in the study was obtained from the European Space Agency (ESA) with $300 \mathrm{~m}$ resolution. The historical map data as well as field inspection, vegetation cover and satellite images were employed to develop the land cover and land use maps.

Soil Map: The runoff amounts are highly dependent of the soil properties such as soil texture, soil hydraulic conductivity (K), and other soil physical properties. Soil samples were collected from five chosen locations within the Al-Masad basin. The depth that the samples were taken from was approximately $20 \mathrm{~cm}$. The Unified Standard Classification was used to determine the texture of the soil samples, as listed in Table (1). A soil map was created for the study area by using a supervised classification with ENVI 4.7 and ArcGIS programs. The created soil map was utilized to model the watershed area.

Weather Data: The weather data that were used in the study are: rainfall depth; relative humidity; maximum and minimum temperatures; solar radiation; and speed of wind. These data have been recorded by Al-Rutba Weather Station for the period between 1995 and 2020. The data were prepared to be ready for simulation and then fed to the model.

The SWAT model employs the DEM to calculate the slope of the catchment and the stream slope length. The calculated slopes by the SWAT model were distributed into four classes. The classified slopes must be covered all slopes of the subbasins.

The input data required by the SWAT model to compute the surface runoff consist of weather and catchment data. The main combinations of input data utilized in this research are summarized in Table (2).

Table 1. Soil texture at Al Masad catchment

\begin{tabular}{|c|c|c|c|c|c|c|}
\hline Sample No. & Easting & Northing & Sand \% & Silt \% & Clay \% & Textural class \\
\hline 1 & $616109.90 \mathrm{~m} \mathrm{E}$ & $3622317.44 \mathrm{~m} \mathrm{~N}$ & 85.1 & 7.3 & 7.6 & Sandy \\
\hline 2 & $615216.76 \mathrm{~m} \mathrm{E}$ & $3632607.51 \mathrm{~m} \mathrm{~N}$ & 33.6 & 52.5 & 13.9 & Silt loam \\
\hline 3 & $611837.92 \mathrm{~m} \mathrm{E}$ & $3627547.43 \mathrm{~m} \mathrm{~N}$ & 77.7 & 9.9 & 12.4 & Sandy loam \\
\hline 4 & $616620.07 \mathrm{~m} \mathrm{E}$ & $3617877.26 \mathrm{~m} \mathrm{~N}$ & 61.3 & 21.1 & 17.5 & Loamy sand \\
\hline 5 & $618608.19 \mathrm{~m} \mathrm{E}$ & $3630156.20 \mathrm{~m} \mathrm{~N}$ & 57.4 & 12.8 & 29.8 & Sandy clay loam \\
\hline
\end{tabular}

Table 2. The input data required by the SWAT model

\begin{tabular}{|c|c|c|}
\hline Category & Parameter name & Model input data \\
\hline \multirow{6}{*}{ Raster data } & \multirow{3}{*}{ Digital elevation model } & Watershed delineation \\
\hline & & Subbasins delineation \\
\hline & & Slope \\
\hline & \multirow{2}{*}{ Land use } & Land use \\
\hline & & Land cover \\
\hline & Soil map & Soil data \\
\hline \multirow{6}{*}{ Time series } & \multirow{5}{*}{ Climate data } & Precipitation \\
\hline & & Temperature \\
\hline & & Windspeed \\
\hline & & Solar radiation \\
\hline & & Relative humidity \\
\hline & Streamflow for calibration and verification & Observed Runoff for 20 rainstorm events \\
\hline
\end{tabular}




\section{Results and Discussion}

\subsection{Model Outputs}

The boundaries of Al-Masad basin, as determined from the DEM, are shown in Figure 3. This basin was fragmented to 33 sub-basins. The land use map that was developed for the study area is shown in Figure 4. The land use map indicates that the dominant land use is "arid area" with indistinctive human activates. A supervised classification was used to classify the soil map based on soil properties of the study area. The area was classified into five main classes: sandy, sandy loam, sandy clay loam, silt loam, and loamy sand. The predominate class in the area was loamy sand, as shown in Figure 5.

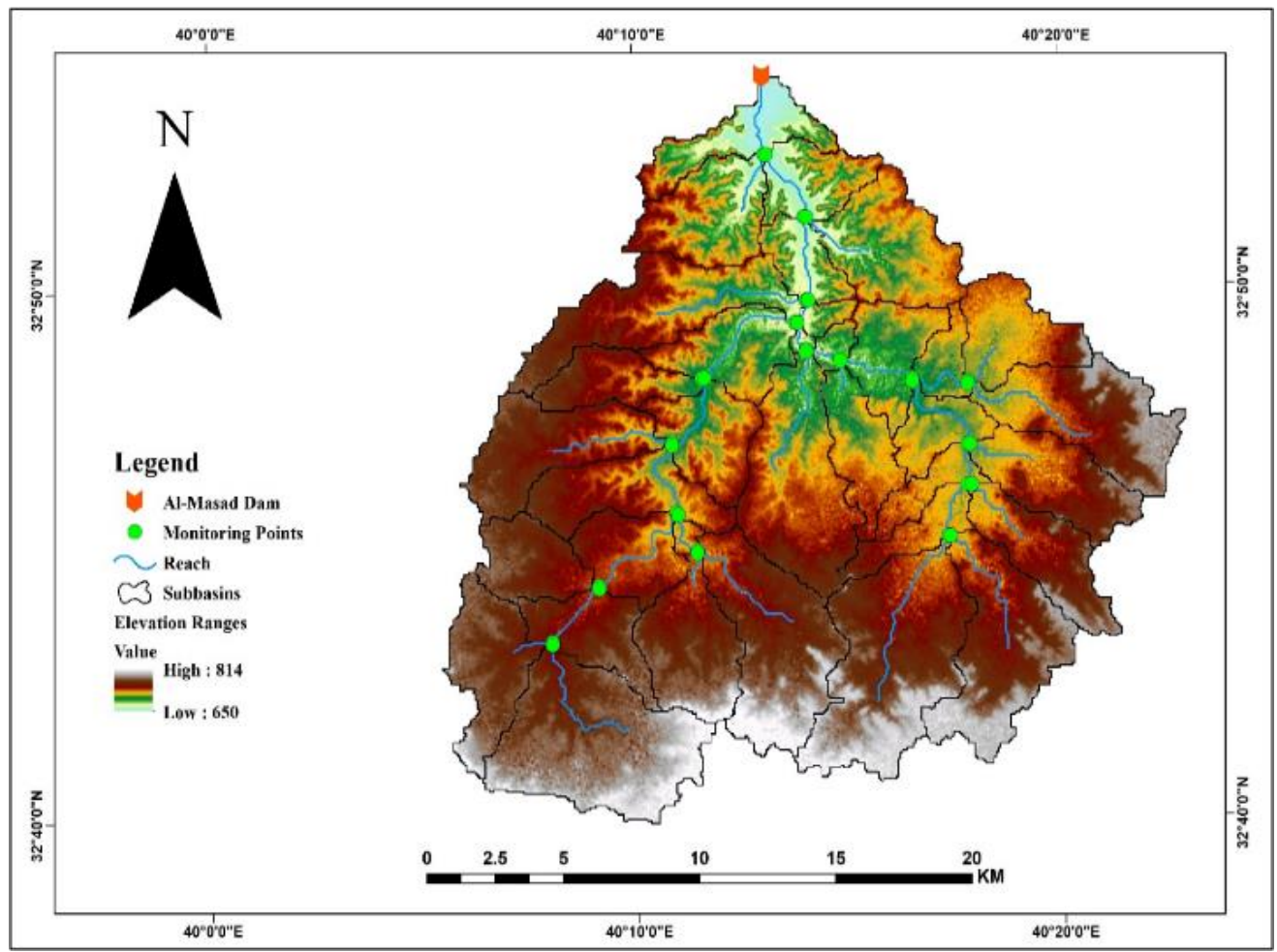

Figure 3. Delineation of sub-basins of the study area

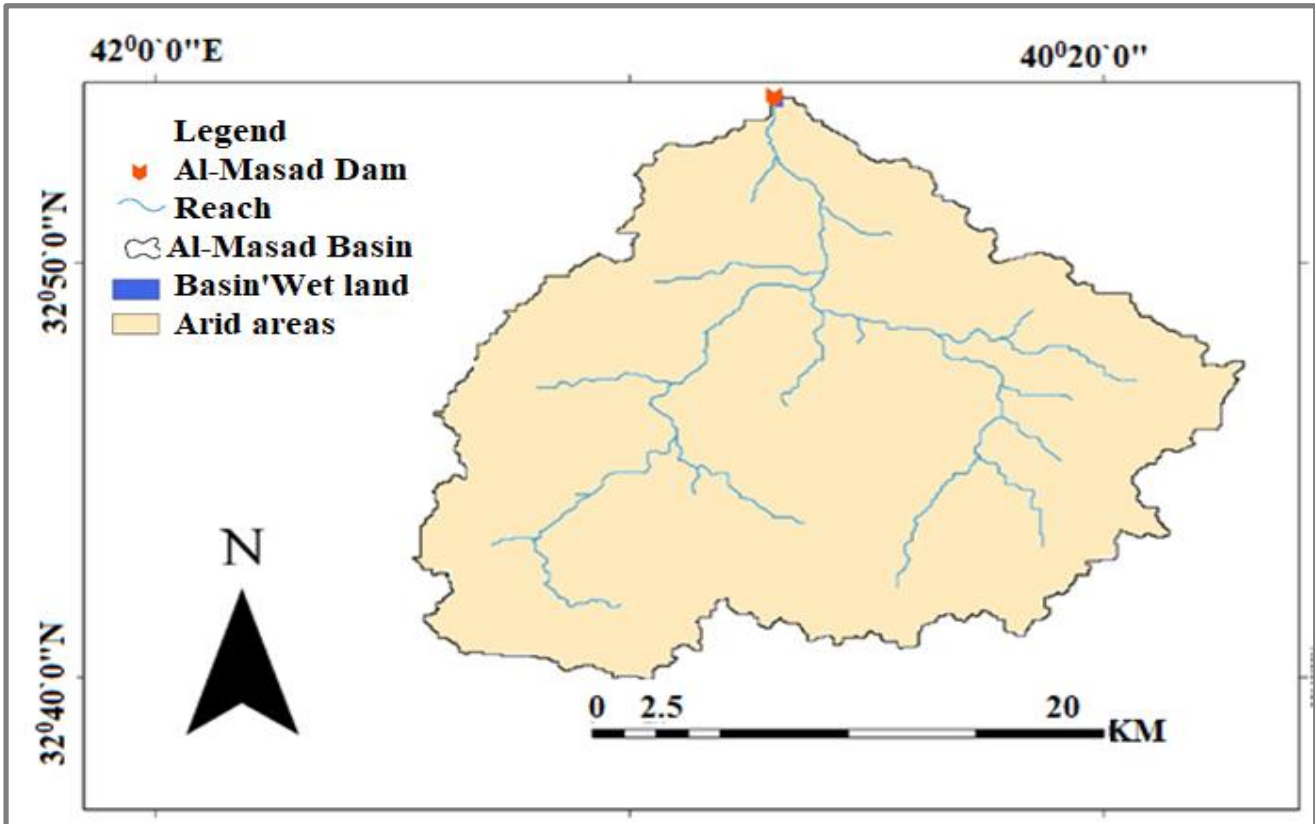

Figure 4. Land use map of the study area 


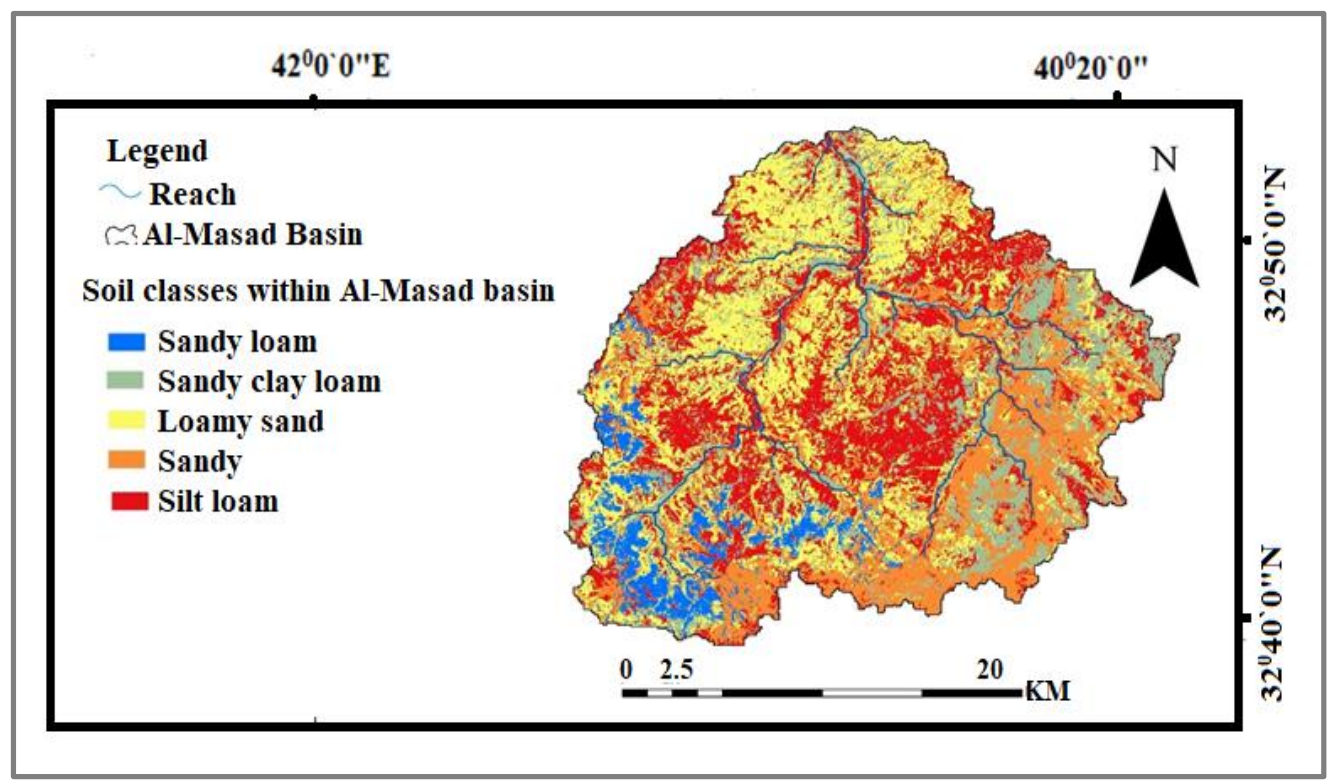

Figure 5. Soil type delineation of the study area

\subsection{Model Calibration and Validation}

The purpose of the model calibration is to obtain a more sufficient and reliable approximation of the predicted and measured data. Field measurements were recorded at the outlet of drainage basin of the valley, after the occurrence of a rainfall, for the period between 2010 and 2014. For the calibration process, the model was applied in order to predict the values of the surface runoff from the basin for two years from 2010 to 2012. The computed statistical parameters RSR, PBias, and NSE for the evaluation of the model were respectively $0.58 \%, 13 \%$, and $0.71 \%$. The results are presented in Figure 6 . The verification process of the model was performed by applying the model on a daily basis between 2012 and 2014 to estimate the values of the surface runoff and then comparing those values to the field measurements. The values of the RSR, PBias, and NSE were estimated as $0.55 \%, 11 \%$ and 0.74 , respectively. The results, as presented in Figure 7, indicated a sufficient agreement between the predicted and the measured values of the surface runoff. This model was applied for the purpose of determining a 10-year forecast, between 2021 and 2030, of drainage basin surface runoff, as can be seen from Figure 8. The statistical parameters including PBIAS, RSR, and NSE have shown that the calibration and the verification of the model led to a better correlation with the measured surface run-off values. Surface runoff prediction for the upcoming 10-year period was 36 times occurring of the runoff with an average value of annual water volume of
$6557.2 \mathrm{~m}^{3}$ for each square kilometer of the catchment. The results indicate that many water harvesting projects can be implemented within the study area due to the significant amount of water that was estimated by the model.

\section{Conclusions}

Satellite images and meteorological data were employed by the SWAT model to predict the surface runoff values of Al-Masad basin in the West Desert of Iraq. The predicted values of the surface runoff were in a good agreement with the measured values. This agreement proves that the SWAT model was a sufficient tool for the accurate prediction of the surface runoff with a minimal time and a lower cost. Although the volume of monitored data needs to be increased to increase the accuracy of the model, the SWAT model can provide valuable data for decision-makers and planning managers in the fields of water resources. The findings of this study will help in selecting the best locations for water harvesting projects such as small dams. The findings will also help to accomplish the designs of these projects that are cost-effective and time efficient. To increase the model accuracy, it is recommended to use an updated DEM with high resolution due to the fact that the resolution of the images that were utilized was $90 \mathrm{~m}$. Moreover, depth that was used to obtain the samples should be increased to increase the reliability of the soil samples. 


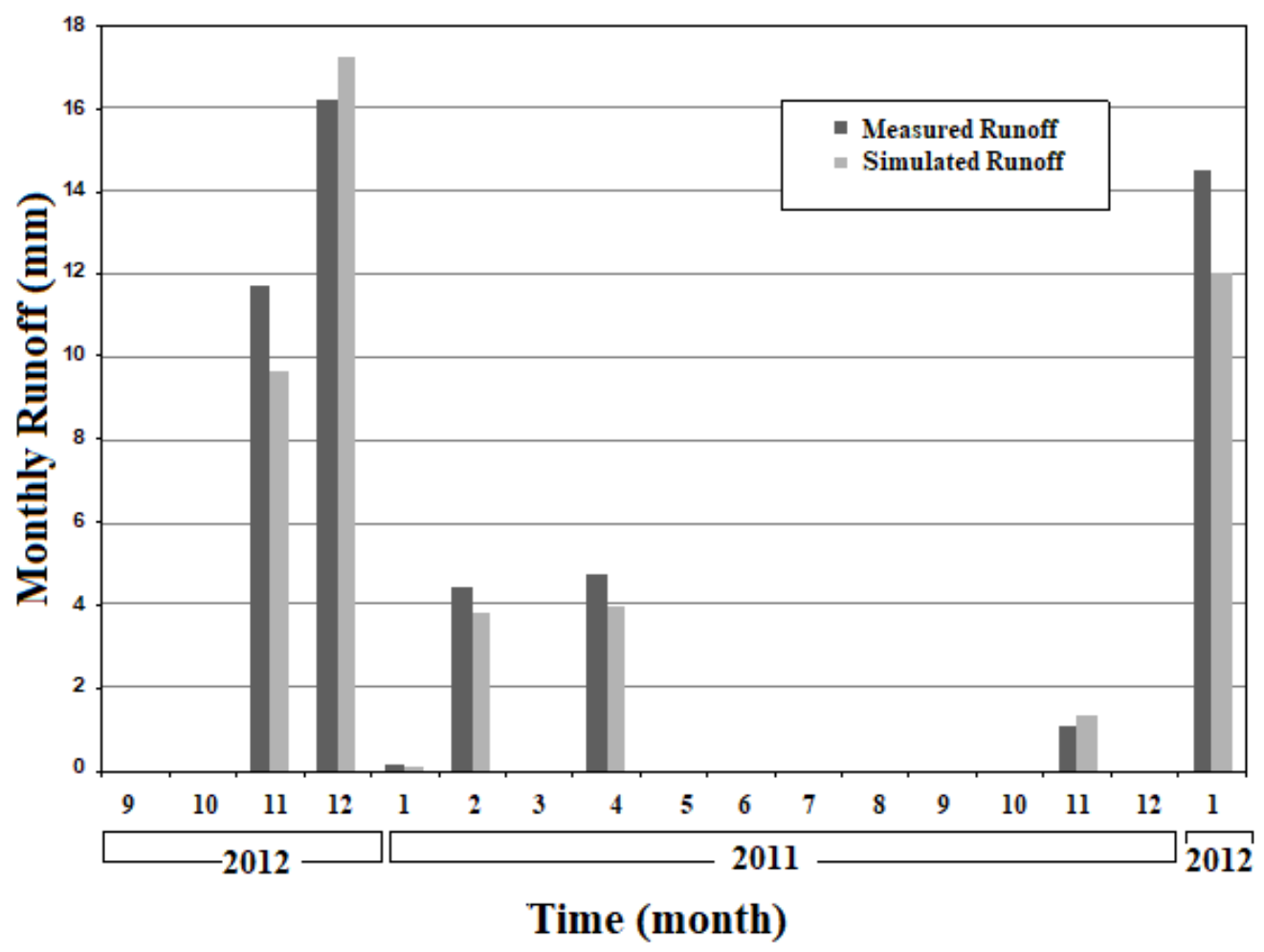

Figure 6. Comparison between measured and simulated monthly flow during the calibration

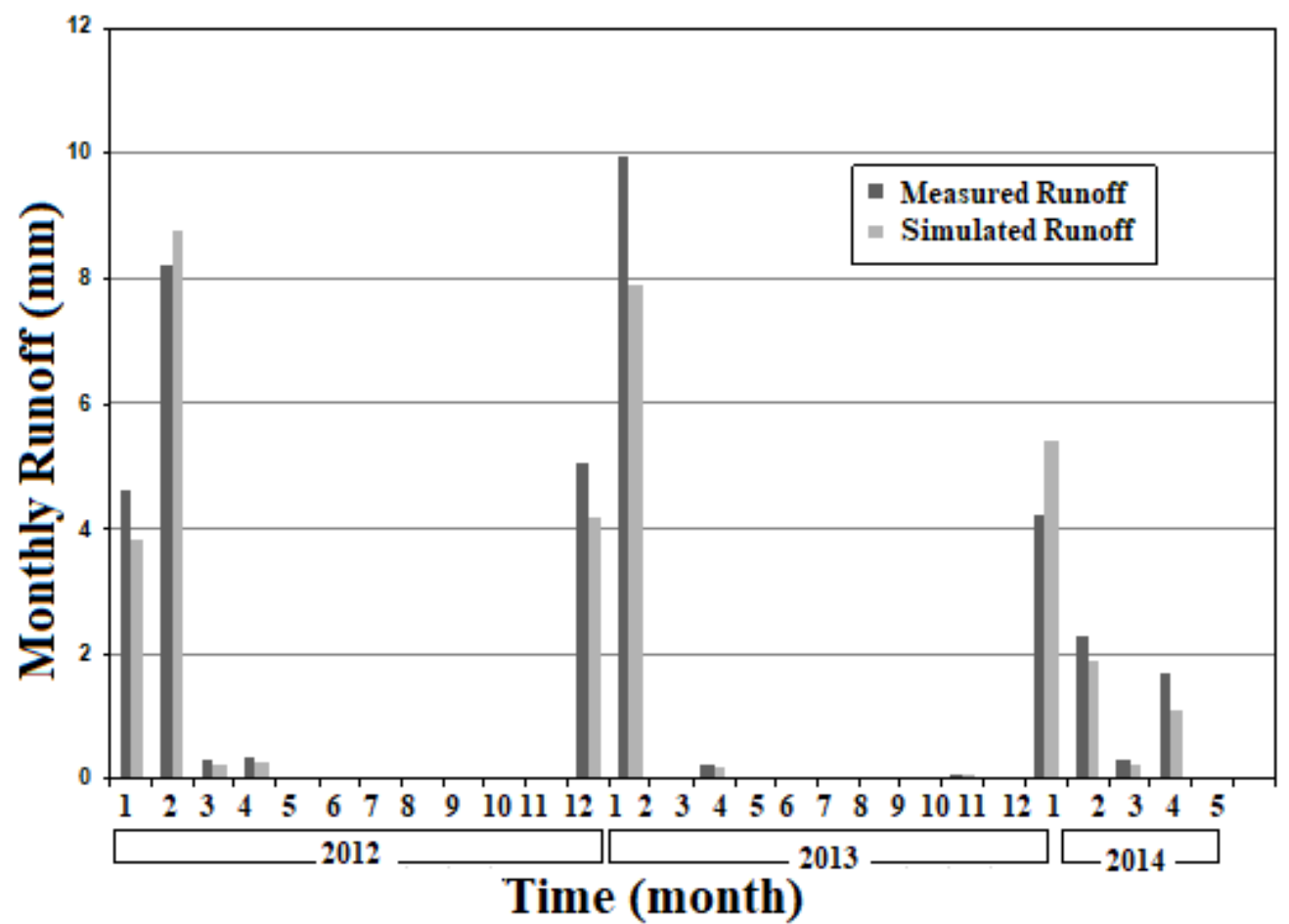

Figure 7. Comparison between measured and simulated monthly flow during the verification 


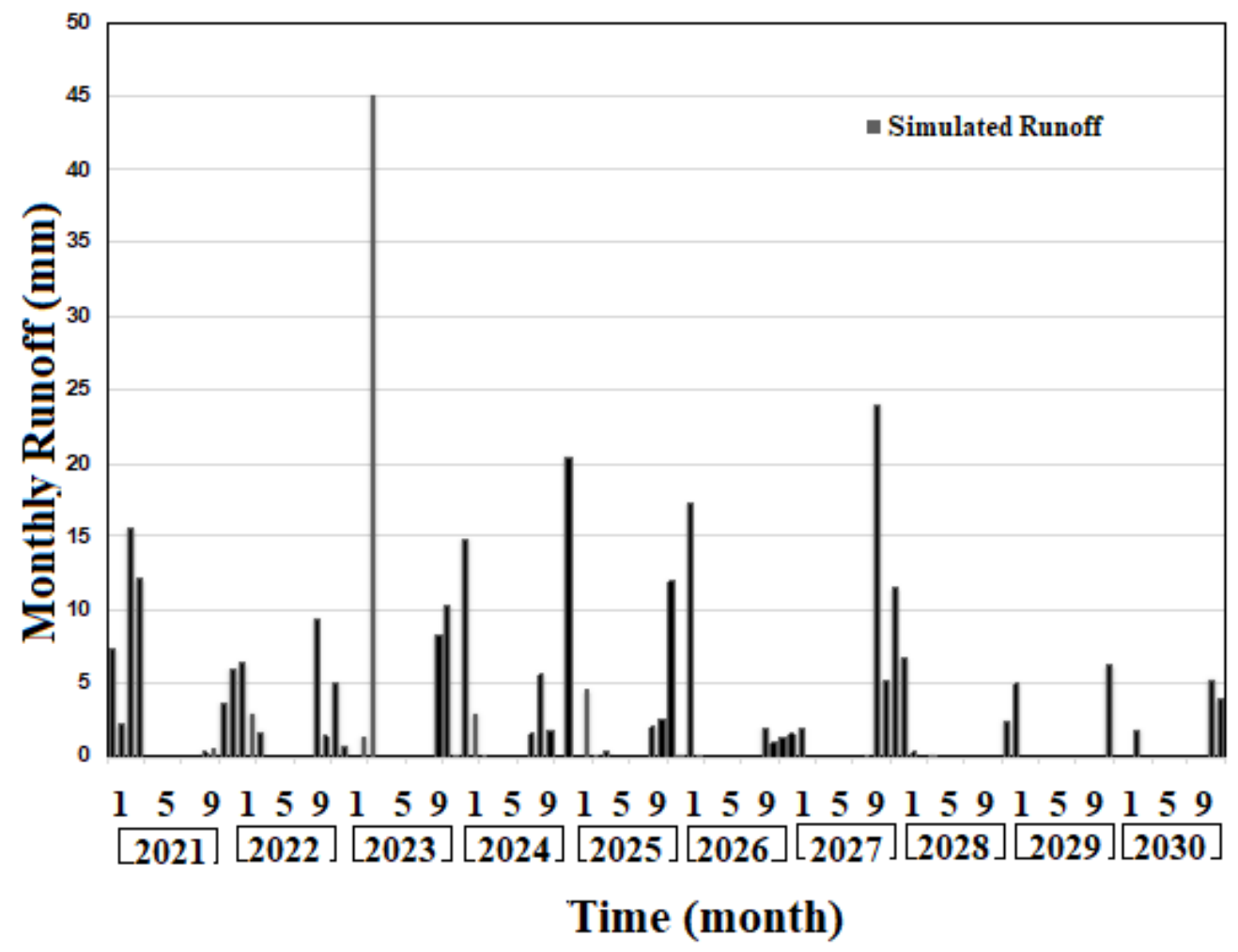

Figure 8. The values of the surface runoff as predicted by the SWAT model

\section{Acknowledgements}

We are very grateful to experts for their appropriate and constructive suggestions to improve this paper.

\section{REFERENCES}

[1] S. P. Simonovic, "World water dynamics: global modeling of water resources," J. Environ. Manage., vol. 66, no. 3, pp. 249-267, Nov. 2002, doi: 10.1006/jema.2002.0585.

[2] A. B. A. Najm, I. M. Abdulhameed, and S. O. Sulaiman, "Water Requirements of Crops under Various Kc Coefficient Approaches by Using Water Evaluation and Planning (WEAP)," Int. J. Des. Nat. Ecodynamics, vol. 15, no. 5, pp. 739-748, Nov. 2020, doi: 10.18280/ijdne.150516.

[3] S. O. H. Al-Shujairi, S. O. Sulaiman, and M. A. Najemalden, "Variations of Major Ionic Composition and Salinity of Tigris River within Iraq," Sulaimani J. Eng. Sci., vol. 2, no. 2, pp. 64-73, Aug. 2015, doi: 10.17656/sjes.10025.

[4] S. O. Sulaiman, N. Al-Ansari, A. Shahadha, R. Ismaeel, and S. Mohammad, "Evaluation of sediment transport empirical equations: case study of the Euphrates River West Iraq," Arab. J. Geosci., vol. 14, no. 10, p. 825, May 2021, doi: 10.1007/s12517-021-07177-1.

[5] S. O. Sulaiman, A. H. Kamel, K. N. Sayl, and M. Y. Alfadhel, "Water resources management and sustainability over the Western desert of Iraq," Environ. Earth Sci., vol. 78, no. 16, p. 495, Aug. 2019, doi: 10.1007/s12665-019-8510-y.
[6] A. H. Kamel, S. O. Sulaiman, and A. Sulaiby Mustaffa, "Study of the Effects of Water Level Depression in Euphrates River on the Water Quality," J. Civ. Eng. Archit., vol. 7, no. 2, pp. 238-247, 2013.

[7] A. Stehr, P. Debels, F. Romero, and H. Alcayaga, "Hydrological modelling with SWAT under conditions of limited data availability: Evaluation of results from a Chilean case study," Hydrol. Sci. J., vol. 53, no. 3, pp. 588-601, 2008, doi: 10.1623/hysj.53.3.588.

[8] A. . Mustafa, S. . Sulaiman, and S. . Shahooth, "Application of QUAL2K for water quality modeling and management in the lower reach of the Diyala River," Iraqi J. Civ. Eng., vol. 11 , no. 2, pp. 66-80, 2017.

[9] A. S. Mustafa, S. O. Sulaiman, and O. M. Hussein, "Application of SWAT Model for Sediment Loads from Valleys Transmitted to Haditha Reservoir," J. Eng., vol. 22, no. 1, pp. 184-197, 2016, [Online]. Available: https://www.jcoeng.edu.iq.

[10] Y. Zhang, J. Degroote, C. Wolter, and R. Sugumaran, "Integration of modified universal soil loss equation (MUSLE) into a gis framework to assess soil erosion risk," $L$. Degrad. Dev., vol. 20, no. 1, pp. 84-91, Jan. 2009, doi: 10.1002/ldr.893.

[11] P. W. Gassman, M. R. Reyes, C. H. Green, and J. G. Arnold, "The soil and water assessment tool: Historical development, applications, and future research directions," Trans. ASABE, vol. 50, no. 4, pp. 1211-1250, 2007.

[12] Nahlah Abbas, Saleh A. Wasimi, and Nadhir Al-Ansari, "Climate Change Impacts on Water Resources of Greater Zab River, Iraq,” J. Civ. Eng. Archit., vol. 10, no. 12, pp. 
1384-1402, Dec. 2016, doi: 10.17265/1934-7359/2016.12.0 09.

[13] L. QIU, F. ZHENG, and R. YIN, "SWAT-based runoff and sediment simulation in a small watershed, the loessial hilly-gullied region of China: capabilities and challenges," Int. J. Sediment Res., vol. 27, no. 2, pp. 226-234, Jun. 2012, doi: 10.1016/S1001-6279(12)60030-4.

[14] A. Jodar-Abellan, J. Valdes-Abellan, C. Pla, and F. Gomariz-Castillo, "Impact of land use changes on flash flood prediction using a sub-daily SWAT model in five Mediterranean ungauged watersheds (SE Spain)," Sci. Total Environ., vol. 657, pp. 1578-1591, Mar. 2019, doi: 10.1016/j.scitotenv.2018.12.034.

[15] Sukru Taner Azgin and Filiz Dadaser Celik, "Evaluating Surface Runoff Responses to Land Use Changes in a Data Scarce Basin: a Case Study in Palas Basin, Turkey," Water Resour., vol. 47, no. 5, pp. 828-834, Sep. 2020, doi: 10.1134/S0097807820050206.

[16] P. W. Gassman, A. M. Sadeghi, and R. Srinivasan, "Applications of the SWAT Model Special Section: Overview and Insights," J. Environ. Qual., vol. 43, no. 1, pp. 1-8, Jan. 2014, doi: 10.2134/jeq2013.11.0466.

[17] S. O. Sulaiman, G. Al-Dulaimi, and H. Al Thamiry, "Natural Rivers Longitudinal Dispersion Coefficient Simulation Using Hybrid Soft Computing Model," in 2018 11th International Conference on Developments in eSystems Engineering (DeSE), Sep. 2018, vol. 2018-Septe, pp. 280283, doi: 10.1109/DeSE.2018.00056.

[18] A. M. Farhan and H. A. Al-Thamiry, "Estimation of the Surface Runoff Volume of Al-Mohammedi Valley for Long-Term period using SWAT Model," Iraqi J. Civ. Eng., vol. 014 , no. 001, pp. 7-12, 2020.

[19] K. Sayl, A. Adham, and C. J. Ritsema, "A GIS-Based
Multicriteria Analysis in Modeling Optimum Sites for Rainwater Harvesting," Hydrology, vol. 7, no. 3, p. 51, Aug. 2020, doi: 10.3390/hydrology7030051.

[20] N. A. Al-Ansari, "Management of Water Resources in Iraq: Perspectives and Prognoses," Engineering, vol. 05, no. 08, pp. 667-684, 2013, doi: 10.4236/eng.2013.58080.

[21] A. M. Noon, H. G. I. Ahmed, and S. O. Sulaiman, "Assessment of Water Demand in Al-Anbar Province- Iraq," Environment and Ecology Research, vol. 9, no. 2, pp. 64-75, Apr. 2021, doi: 10.13189/eer.2021.090203.

[22] S. Pang, X. Wang, C. S. Melching, and K.-H. Feger, "Development and testing of a modified SWAT model based on slope condition and precipitation intensity," J. Hydrol., vol. 588, no. May, p. 125098, Sep. 2020, doi: 10.1016/j.jhydrol.2020.125098.

[23] T. Aawar and D. Khare, "Assessment of climate change impacts on streamflow through hydrological model using SWAT model: a case study of Afghanistan," Model. Earth Syst. Environ., vol. 6, no. 3, pp. 1427-1437, Sep. 2020, doi: 10.1007/s40808-020-00759-0.

[24] J. R. Williams, K. G. Renard, and P. T. Dyke, "EPIC: A new method for assessing erosion's effect on soil productivity," $J$. Soil Water Conserv., vol. 38, no. 5, pp. 381-383, 1983.

[25] J. G. Arnold, R. Srinivasan, R. S. Muttiah, and J. R. Williams, "LARGE AREA HYDROLOGIC MODELING AND ASSESSMENT PART I: MODEL DEVELOPMENT ' basin scale model called SWAT ( Soil and Water speed and storage, advanced software debugging policy to meet the needs, and the management to the tank model ( Sugawara et al ., 1," vol. 34, no. 1, pp. 73-89, 1998.

[26] J.R. WILLIAMS, “The EPIC model. In: Singh, V.P., Ed.," in Computer models of watershed hydrology, Chapter 25, Water Resources Publications, Highlands Ranch., 1995, pp. 909-1000. 